\title{
RETHINKING THE OTHER FOR MULTICULTURAL EDUCATION - FOCUSED ON THE PHILOSOPHY OF BUBER AND LEVINAS
}

\author{
Seungeun Choi \\ Inha University/Research Professor (Republic of Korea)
}

\begin{abstract}
The number of foreigners residing in Korea exceeded 2.5 million for the first time ever. As the ratio of foreigners to the total population approaches $5 \%$, it is evaluated that Korea has actually entered a multicultural society. It is known that among the types of foreigners staying there are many young foreigners who visit Korea for the purpose of employment. The number of marriage immigrants was 16,025 , an increase of $4.3 \%$ from the previous year. Of these, $82.6 \%$ were women. Entering a multicultural society in a situation where empathy for each other is insufficient can lead to social conflict. In particular, in the COVID-19 pandemic, hostility toward foreigners is more prevalent, and hatred for strangers is increasing.

This study critically analyzes these social phenomena and seeks to raise the philosophical basis for multicultural education by establishing a concept with a new perspective on the other. This paper focuses on the philosophy of Buber and Levinas. By establishing 'I and You' as a meeting, Buber presented a new relationship with others. Meanwhile, Levinas emphasized human ethics and responsibility as the absolute and infinite being of the other.

According to Buber, in the world there is a relationship between 'I-You' and 'I-It', and in order to live a true life, you must establish a relationship between 'I and you'. The relationship between 'I and it' is a temporary and mechanical relationship where objects can be replaced at any time by looking at the world from an instrumental point of view. However, the relationship between 'I and You' is a relationship that faces each other personally, and the only 'I' that cannot be changed with anything and the 'You' that cannot be replaced exist in deep trust.

In phenomenology of otherness, Levinas intends to describe the encounter with the something outside the subject. The concepts of possession, distinctiveness and understanding are replaced by those of approaches, proximity, care and fecundity.

In Korean society, a policy that seeks to use foreigners as human resources and, especially in the case of marriage immigrant women, as a solution to a society with low birthrates along with the labor force, shows how society treats others. Therefore, multicultural education must rethink the existence and dignity of human beings through the perspective of the other as asserted in the philosophy of Buber and Levinas.
\end{abstract}

Keywords: Other, multicultural education, philosophy, Buber, Levinas.

\section{Introduction}

The number of foreigners residing in Korea exceeded 2.5 million for the first time ever. As the ratio of foreigners to the total population approaches $5 \%$, it is evaluated that Korea has actually entered a multicultural society. It is known that among the types of foreigners staying there are many young foreigners who visit Korea for the purpose of employment. The number of marriage immigrants was 16,025 , an increase of $4.3 \%$ from the previous year. Of these, $82.6 \%$ were women (Ministry of Justice, 2021). Entering a multicultural society in a situation where empathy for each other is insufficient can lead to social conflict. In particular, in the COVID-19 pandemic, hostility toward foreigners is more prevalent, and hatred for strangers is increasing.

This study critically analyzes these social phenomena and seeks to raise the philosophical basis for multicultural education by establishing a concept with a new perspective on the other. This paper focuses on the philosophy of Buber and Levinas. By establishing 'I and You' as a meeting, Buber presented a new relationship with others. Meanwhile, Levinas emphasized human ethics and responsibility as the absolute and infinite being of the other. 
Multicultural education is an idea, an educational reform movement, and a process (Banks, 1997). Multicultural education values different student cultures and prepares students to thrive in a diverse world. At its core, multicultural education fosters equality, justice, and equity, and it establishes the reality of philosophical ideals in classroom environments. In spite of this concept of multicultural education, aversion to difference is increasing in Korean society. In addition, human alienation, dehumanization, and self-loss, which become increasingly serious, seem like pathological phenomena in which communication is absent.

In Korean society, a policy that seeks to use foreigners as human resources and, especially in the case of marriage immigrant women, as a solution to a society with low birthrates along with the labor force, shows how society treats others. Therefore, multicultural education must rethink the existence and dignity of human beings through the perspective of the other as asserted in the philosophy of Buber and Levinas.

\section{Relationships in Buber's philosophy}

Buber's philosophy was built on existentialism. He said that the true existence only emerges from the human face-to-face, that is, the encounter, as an interaction between a free man and another man. The essence of Buber's thought is that through encounters, people are guided toward being human. "Humans bring a dramatic change in their lives due to the opportunity of meeting. Through these changes, human beings are transformed from beings as humans to beings that become humans (Buber, 1956)."

Buber's thoughts on the relationship between 'I-You' suggest the concept of community needed in modern society. He divided the two fundamental orders of the human world into a personal community in which genuine dialogue is based on the relationship of 'I-You' and a collective society in which a monopoly is formed based on the relationship of 'I-it'. He regarded humans as not as an isolated existence, but as an existence to meet and communicate.

Buber argued that humans are creators who shape their existence through relationships. Relationships are established in sincere dialogue, and dialogue makes it possible to meet personalities. It is a situation for self-discovery. Therefore, the relationship between 'I-You' is a relationship of a whole person and a personal dialogue. "Relationship in education is a pure conversation" (Buber, 1979). The composition and growth of character is the task that teachers and students want to achieve in one meeting place called education.

Through his thoughts on the relationship between 'I-You', Buber's philosophy goes beyond individual existentialism to present the relationship between humans and nature, between humans and humans, and between humans and mental beings as a prototype of the relationship. This is why human relational coexistence is important in a multicultural society. According to Buber (1979), human self-loss and atomization stem from the broken relationship between humans and humans. Humans are beings that cannot be objectified, and they must become 'I and You' that coexist as personalities. "Every true life is an encounter." A true community does not consist only of people having feelings for each other, but it begins with all human beings entering into a living interrelationship (Buber, 1979). In other words, what matters is the area of the relationship that is to be discovered or rediscovered.

\section{The other in Levinas' philosophy}

In the concept of 'I-You', the wall of self disappears, and relationships are formed in my essence. You cannot think of a relationship without "you' who fully affirms this point. The existence of "you" is a milestone in finding another existence, and the encounter is a priori existence or birth. In this way, humans are in a relationship even though they did not intend. In this context, Levinas perceives human beings not as subjects at all, but as "links of encounters", and recognizes me as being not as real, but as a category (Levinas, 1963). According to Levinas, the other is neither manipulated nor controlled. They are not trapped in the horizons of understanding or existence that Heidegger emphasizes. It is the other who is not under any category. In addition, the externality of the other is neither spatial nor conceptual (Levinas, 1997). In this way, Levinas's main philosophical concern is that it is inherently impossible to make the other a subject of understanding, and that the otherness must be preserved as it is.

The other exists as 'manifestation', that is, 'appearing'. At this time, the other appears through a face that 'shows the existence of another person in a single way.' Here, the face does not mean any expression or outline. The face contains infinite otherness implicitly. Responsibility is derived from the other, the face of the other, and the close relationship between me and the other (Levinas, 1979).

Levinas calls responsibility as the essential and fundamental structure of the subject and the condition of subjectivity. Responsibility refers to the responsibility of others, those who have nothing to 
do with me, and those who do not see me. Also, it is a responsibility that goes beyond my actions. I take the responsibility of the other. In this respect, the responsibility Levinas refers to is clearly distinguished from the self-responsibility or responsibility of conduct, which is fundamental in law. At this time, the other refers to the weak, the poor, the widow and the orphan above all else. For these other people I owe. I must respond to the request of the other as 'the first person'(Levinas, 1979). The point to note here is that, according to Levinas, my responsibility to the other is unlimited. In this respect, responsibility to the other is different from tolerance. Tolerance starts from the same person, at best, it only refers to limited liability. However, the other's face appeals for unlimited responsibility.

\section{Multicultural society and others}

The relational attribute of 'I-You' ultimately leads to the creation of 'Between-being (Zwischensein)' as a third concept. It refers to a communal existence formed by the relationship between 'I-You', which is considered the core of Buber's communicative thoughts (Rotenstreich, 1963).

This is not a real existence, but a relational communication thought by implying the meaning of a relational existence. Between-being is not another third entity between 'I and You', but it can be referred to as 'being together' or 'Between men (Zwischenmensch)', which is created by 'I and You' together. The 'I' who creates these between-beings must be a personal being. Thus, between-being can be defined as a mystical concept that creates a new relationship. Specifically, the existence between 'I and You' is formed by standing face to face (Marcel, 1963).

Levinas evaluates the between-being as belonging to a third being, not a creative center, not as a field of force with both a subject and an object. However, according to him, there is no independent existence, and it has a special transcendental property in which 'I and You' form a special encounter. In other words, between-being does not have a substantial concept of existence, such as the content of existence, the object representation of existence, or the existence that can be described, and implies the meaning of expressing existence as a whole (Levinas, 1963).

The important point is that human personal communication relationships do not exist in the inner world or the vast outer world of each human being, but are created between these humans. As an inter-being, the self becomes the subject by being in charge. The subject stands tall as an irreplaceable person, as the first person, as a being who is not swung by anything. I cannot deny this responsibility. The reason is that this responsibility is the highest dignity of the irreplaceable (Levinas, 1961). By taking responsibility for the other, the self finds the identity necessary to become an authentic subject. Only when ethical subjectivity is established can it become a condition for a multicultural society.

The fear that prevails in today's society is mixed with anger, criticism, and envy. Fear blocks rational thinking, poisons hope, and hinders constructive cooperation for a better future (Nussbaum, 2018). Hate for others begins with fear. We must free ourselves from fear of others and build solidarity together as members of a multicultural society.

In a multicultural society, solidarity with the other means that it is not simply an external solidarity through coexistence of various cultures, but an internal communication based on ethics and absolute responsibility toward others. This is because dynamic coexistence is possible when individual beings in various cultures go beyond acknowledging their differences.

\section{Conclusion}

Multicultural education is a process because its goals are ideals that teachers and administrators should constantly strive to achieve. A major goal of multicultural education is to help students from diverse cultures learn how to transcend cultural borders and to engage in dialog and civic action in a diverse, democratic society. From this goal of multicultural education, the issue of restoring humanity through the personal "encounter" of 'I and You' must go to the issue of humanity. Since this is a matter of education, it takes place when the true encounter between 'I and You' is emphasized in the current dehumanized education.

We cannot be totally indifferent to the needs of others. The reason is that the other is a necessary condition for the formation of my subjectivity. I cannot make me a whole subject unless I distinguish myself from what I am not. The question of who I am is bound to be an ethical matter. Because who I am is always influenced by what is outside me (Levinas, 1979). In the neoliberal system, Korean society tended to use multicultural members, especially marriage immigrant women, children of multicultural families, and foreign workers as human resources. We must rethink the dignity of all humans. In a multicultural society, all members are responsible for each other. We coexist through encounters in a conversational relationship between 'I and You'. For a sustainable multicultural society, we must become an ethical being responsible for others. 


\section{References}

Banks, J. A. (1997). Multicultural Education: Characteristics and Goals. In J. A. Banks \& C. A. M. Banks, (Eds.). Multicultural Education: Issues and Perspectives (3rd ed., pp. 3-31). Boston: Allyn and Bacon.

Buber, M. (1965). Between Man and Man, M. Friedman(trans), New York: The MacMillan.

Buber, M. (1979). I and Thou. W. Kaufman(trans.), New York: Charles Scribner's Sons.

Friedman (eds.), Martin Buber, Stuttgart: Kohlhammer Verlag, 119 134.

Levinas, E. (1961) Totality and Infinity: An Essay on Exteriority. A. Lingis (trans.), Duquense University Press.

Levinas, E. (1963). Martin Buber und die Erkenntnistheorie. In P. A. Schilpp and M.

Levinas, E. (1979). Time and the Other. R. A. Cohen (Trans.) Duquense University Press.

Levinas, E. (1997). Heidegger, Gagarin and Us, in: Difficult Freedom: Essays on Judaism. Seán Hand (trans.), The Johns Hopkins University Press.

Marcel, G. (1963). Ich und Du bei Martin Buber. In P. A. Schilpp and M. Friedman (eds.), Martin Buber, Stuttgart: Kohlhammer Verlag.

Marcel, G. (1963). Ich und Du bei Martin Buber. Schilpp and Friedman.

Ministry of Justice (2021). Monthly statistics on immigration·foreigner policy. Republic of Korea.

Nussbaum, M. C. (2018). The Monarchy of Fear: A Philosopher Looks at Our Political Crisis. Simon \& Schuster, Inc.

Roberts-Cady, S. E. (2009). Rethinking Justice with Levinas. In Essays on Levinas and Law. Palgrave Macmillan, London.

Rotenstreich, N. (1963), Gruende und Grenzen von Martin Bubers dialogischem Denken. In P. A. Schilpp and M. Friedman (eds.), Martin Buber, Stuttgart: Kohlhammer Verlag. 